\title{
The Effects of Electronic and Other External Control Methods on Stuttering: A Review of Some Research Techniques and Suggestions for Further Research
}

By JOHN W F. BOHR, B.A. Honores (Pret.) Senior Research Officer, National Institute for Personal Research, South African Council for

Scientific and Industrial Research, Johannesburg.

\section{INTRODUCTION}

During the course of a series of studies aimed at determining the relationship between performance under conditions of delayed auditory feedback (DAF) and performance on three other tests (visual and auditory reaction times and the Stroop Reading Test), the author's interest was aroused in the experimental work of Cherry, Sayers and Marlund (5), on the inhibition of stuttering by means of external control.

The author's experimental work in the field of DAF among 126 English-speaking South African university students, all of whom were normal speakers, indicated that those students with a former history of stuttering typically showed a smaller discrepancy in reading times than others without such history, when performance under two conditions were compared, viz. reading i). with immediate and ii). with delayed auditory feedback.

In normal speech the subject constantly monitors his speech by perception of his output through both exteroceptive and proprioceptive cues. DAF brings about a disruptive effect on the former, and masks the tissueborne auditory cues to the hearing mechanism, without affecting the remainder of proprioceptive cues. It may be thought that the further diminution of proprioceptive cues would make coherent speech impossible, but this is not the case, as has been demonstrated by Ladefoged (9). He excluded exteroceptive speech monitoring by means of a loud masking noise in earphones worn by the subject, whose perception of tissueborne acoustic cues was also masked by the loud noise in the earphones. In an attempt to diminish other proprioceptive cues to the subject, Ladefoged had him suck amethococaine tablets, which produced local anaesthetization of the surface of the lips, tongue and mouth interior. Even under these conditions of considerable diminution of both exteroceptive and proprioceptive cues, the subject was able to produce intelligible speech. Probably the subject was still able to perceive a limited number of reduced proprioceptive cues concerning muscle stretch in those areas of the lips, tongue and larynx unaffected by the amethococaine.

\section{DELAYED AUDITORY FEEDBACK (DAF)}

When a speaker is subjected to DAF he hears his recorded voice a fraction of a second (about 180 milliseconds) after utterance, through a headset or earphones. The system is so arranged that the delayed feedback is at a level high enough to mask the tissueborne auditory cues to the hearing mechanism. Thus the auditory monitoring of speech is disrupted, although proprioceptive cues remain unaffected. With most subjects this disruption of normal auditory speech monitoring produces very marked changes in speech. Lee, who published the first paper on DAF (10), refers to these effects as "startling" and says of DAF: " ... it will cause the person to stutter, slow down while raising his voice in pitch and volume, or stop completely". Working in the same field simultaneously with Lee, but independently of him, Black reported (1) that DAF: " . . . may produce near traumatic effects that include the blocking of speech, facial contortions, the prolongation and slurring of sounds, and repetitions of sounds and syllables." Black states that the disruptive effect of DAF is most marked when the delay time of DAF is between 180 and 220 milliseconds, which approximates the mean syllable duration for average speakers.

Apparatus for producing DAF has been described by Black ( 1 and 2 ), Böhr ( 3 and 4 ), Fairbanks and Jaeger (6), Hanley and Tiffany (7), Marple and Morrill (12), and Tiffany, Hanley and Sutherland (14). Typically, a modified magnetic tape recorder is used. The recorder is fitted with two 
heads (one for recording and the other for simultaneous playback of the recorded signal) and the output from the playback head is fed into an additional playback amplifier. The subject hears the output from the playback head, suitably amplified by the playback amplifier, through earphones or a headset. The degree of delay in the system is dependent upon a number of factors, viz. physical separation between recording and playback heads, speed of tape transport, and the existence or otherwise of devices for lengthening the tape loop between the recording and playback heads.

The system devised by the author is illustrated in Figures 1 and 2. In Figure 1 the modified tape recorder appears in the centre with the playback amplifier on the right. The headset shown is part of a laboratory-type audiometer; for field use the author employs either a set of earphones or a specially constructed portable headset containing two inverted-cone loudspeakers. In Figure 2 the two heads can be seen in the lower centre. The variable loop controller is shown centred between the two reels, while the set of interchangeable capstans are displayed above the left-hand tape reel. By means of the interchangeable capstans, which control the speed of tape transport, and the variable loop controller it is possible to obtain delay times ranging from 122 milliseconds to 897 milliseconds. The physical separation between the two heads is such that a delay time of 183 milliseconds is obtained when the tape is threaded straight through between heads and the speed of tape transport is $7 \frac{1}{2}$ inches per second.

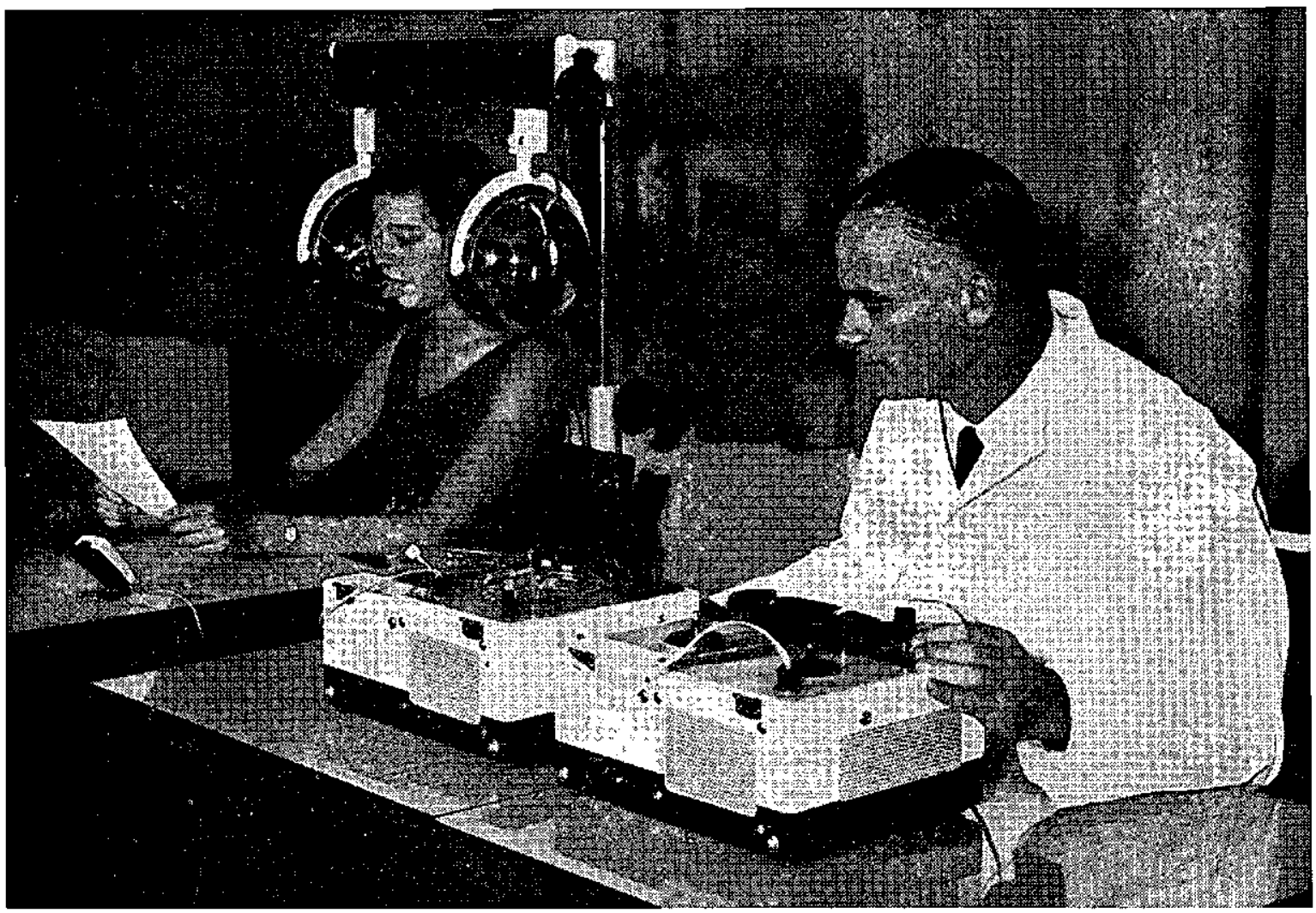

Fig. 1 DAF System devised by author 


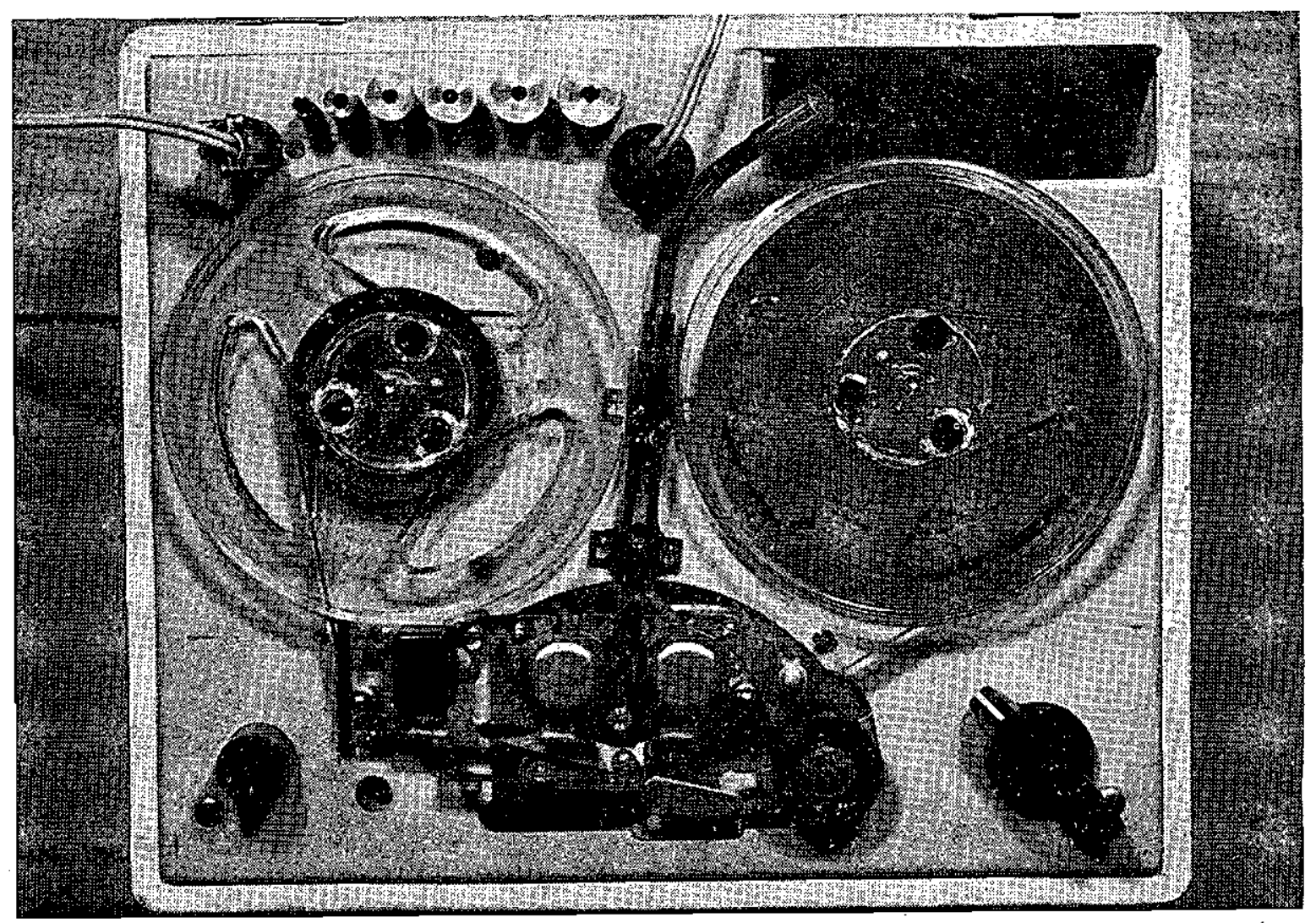

Fig. 2 Modified tape recorder for DAF

\section{SOME SOUTH AFRICAN RESULTS FROM DAF EXPERIMENTS}

Using the apparatus described above, 126 English-speaking second-year students without current speech defects were tested at the Universities of Cape Town, Rhodes and Natal (Pietermaritzburg and Durban). Each subject was required to read the GRANDFATHER passage twice in succession. (This pássage by Van Riper (15) contains all English speech sounds). For each reading the subject wore a portable headset. During the first reading he heard his voice with direct (immediate) feedback through the headset, and during the second reading he heard his voice through the headset with a delay time of 183 milliseconds. The results of this test series appear in Table 1.
These results reveal that DAF produces a marked reduction in reading speed for both male and female subjects. When the méans unly are considered, there is a closer ratio between the two reading times for males than for females. However, there is a greater range over which male performances vary both with direct and delayed auditory "feedback, as shown by the larger standard deviations for the male sample "under both reading conditions. One of the female subjects reported having a slight stutter at an earlier age. Her reading times were 50 and 100 seconds for direct and delayed auditory feedback respectively, giving a ratio of .50 between the two performances, well below the means of both female and male groups. In the male sample there were five subjects with an earlier stuttering history. Their per-formances are' listed in Table 2. 
TABLE 1. READING TIMES IN SECONDS - GRANDFATHER PASSAGE

\begin{tabular}{|l|l|c|c|c|}
\hline \multicolumn{1}{|c|}{ Males } & Mean & $\begin{array}{c}\text { Direct } \\
\text { Feedback }\end{array}$ & DAF & Ratio: $\frac{\text { Direct Feedback }}{\text { DAF }}$ \\
\hline $\mathrm{n}=58$ & Standard deviation & $45.6^{*}$ & $61.8^{*}$ & .74 \\
\hline \begin{tabular}{l} 
2. Females \\
\hline $\mathbf{n}=68$
\end{tabular} & Mean & $6.3^{*}$ & $16.1^{*}$ & - \\
\hline $45.9^{*}$ & $65.1^{*}$ & .71 \\
\hline
\end{tabular}

: Significant beyond the $.05 \%$ level.

TABLE 2. READING TIMES (SECONDS), 5 MALE FORMER STUTTERERS

\begin{tabular}{|c|c|c|c|}
\hline Subject & $\begin{array}{c}\text { Direct } \\
\text { feedback }\end{array}$ & DAF & Ratio: $\frac{\text { Direct Feedback }}{\text { DAF }}$ \\
\hline A & 43 & 33 & 1.303 \\
\hline B & 45 & 56 & .804 \\
\hline C & 46 & 48 & .958 \\
\hline D & 46 & 58 & .793 \\
\hline E & 46 & 41 & 1.122 \\
\hline $\begin{array}{c}\text { Mean for } \\
\text { group }\end{array}$ & $\begin{array}{r}45 \\
\text { sd }=1.166\end{array}$ & $\begin{aligned} 47 \\
\text { sd }=9.325\end{aligned}$ & .957 \\
\hline
\end{tabular}


If only those males $(n=53)$ with no reported stuttering history are considered their mean reading times with direct and delayed feedback are 45.623 secs. $(\mathrm{sd}=6.56)$ and 63.132 secs. $(s d=15.883)$ respectively. An $F$ and t-test on the results of non-stutterers and former stutterers revealed a very significant difference $(.001 \mathrm{p} .0005)$ in the standard deviations of the groups with direct feedback, but no significant difference between the means. Under DAF, the standard deviations of the groups do not differ significantly, but there is a significant difference between the means $(.025 \mathrm{p} .01)$. In effect the 5 former stutterers are less affected in reading time under DAF than the 53 nonstutterers. Although the small sample size of former stutterers precludes any final conclusion, the author tentatively infers that the recovered stutterer may have developed a technique whereby he tends to ignore auditory feedback cues and to rely more heavily on proprioceptive cues for speech monitoring.

If this hypothesis holds, it presents the possibility of utilizing DAF as a prognostic measure during speech therapy. Those subjects showing the smallest discrepancy in reading times under direct and delayed auditory feedback could be expected to benefit most from speech therapy, and vice versa. Alternatively DAF could be employed as an indicator of the progress of the stutterer during speech therapy. It should be emphasized that these suggestions are put forward tentatively at this stage, and should be considered as suggestions for further research, which will indicate whether they are warranted.

A further suggestion emanating from these preliminary findings is the consideration by speech therapists of emphasizing, during therapy, that subjects should attempt to rely more heavily during speech on proprioceptive cues and attempt to ignore the auditory speech cues, which in the case of stutterers actually hamper speech and tend to mediate stuttering, as shown by the work of Cherry, Sayers and Marlund (5).

\section{AN EXPERIMENT USING EXTERNAL CONTROL FOR STAMMERING}

A number of forms of external control to distract the stutterer from the auditory cues in his own voice have been proposed by Cherry, Sayers and Marlund (5) for experimental and clinical use with stutterers. These include speech shadowing, simultaneous reading from the same text, or from different texts, gibberish, whispering, reversed speech, DAF, white noise masking, low-pitch masking, etc., all of which tend to produce improved speech production by stutterers in routine reading.

Before dealing with his experiments in external control with a stutterer, the author wishes to present a brief recapitulation of each of these techniques:

a. Speech shadowing. The experimenter reads aloud or speaks extempore, and the subject attempts to copy this speech pattern aloud, but does not see the text (when used).

b. Simultaneous reading. The experimenter reads aloud, while the subject also reads aloud from the same text.

c. Use of different texts. Both experimenter and subject read aloud from different texts.

d. Gibberish. Experimenter and subject start reading aloud from same text; while test is under way experimenter changes without warning into meaningless sounds (gibberish).

e. Whispering. The experimenter reads aloud, while the subject reads the same passage in a whisper.

f. Reversed speech. The subject reads aloud, while a reversed speech recording is played back to him through earphones from a gramaphone record or tape recording.

g. DAF. The subject reads, aloud, his voice being recorded on magnetic tape and played back to him through a headset a fraction of a second after the utterance of each sound.

h. White noise masking. The subject reads aloud, while a broad band of noise evenly distributed throughout the audio spectrum, and electronically generated, is fed into the headset he is wearing. 
i. Low-pitch masking. The subject reads aloud, while a sine wave of about 140 cycles per second (cps) is fed into the headset he is wearing.

All the above forms of external control can have the effect of improving the reading of stutterers. It can be seen that those forms listed from a. to e. above can be applied without any electronic devices, whilst those listed from $f$. to $i$. require somewhat elaborate apparatus.

Cherry et.al. have demonstrated that white noise masking can produce a differential effect on the inhibition of stuttering, depending on the portion of the audio spectrum reaching the subject: When the white noise is supplied to the subject through a low pass filter which passes all audible noise below $500 \mathrm{cps}$, the mean reduction in breakdown (stuttering) time is $95 \%$, plus or minus $5 \%$. When the white noise is supplied to the subject through a high pass filter which passes audible noise above $500 \mathrm{cps}$, the mean reduction in breakdown (stuttering) time is only $35 \%$. plus or minus $37 \%$. Thus white noise below $500 \mathrm{cps}$ produces a greater improvement in speech production than that above 500 cps. metronome technique of unobtrusively accentuating speech rhythm whereby he can reduce his stutter under normal circumstances. When excited, he omits the metronome hand signals and stutters more than usual. He underwent the experimental series on the clearly-stated understanding that he was participating in the replication of a series of experiments originally performed in London, and was not undergoing a form of therapy.

Three reading passages were used in this series: a randomly-selected passage from a periodical and two standard reading passages, each containing all the speech sounds in English. The two standard passages were Van Riper's GRANDFATHER passage (16) and ARTHUR THE YOUNG RAT, by Johnson, Brown, Curtis, Edney and Keaster (8).

Throughout the series of tests the subject wore a portable headset, through which he received all instructions and external control signals. This procedure was followed so that the wearing of the headset did not in itself constitute an experimental variable.

The results of this experimental series are presented in Table 3.

TABLE 3. READING TIMES (SECONDS) WITH AND WITHOUT EXTERNAL CONTROLS

\begin{tabular}{|c|c|c|c|}
\hline $\begin{array}{c}\text { Test } \\
\text { Sequence }\end{array}$ & $\begin{array}{l}\text { Reading } \\
\text { Passage }\end{array}$ & Circumstances of Test & $\begin{array}{c}\text { Reading } \\
\text { Time }\end{array}$ \\
\hline 1. & Grandfather & Subject reads without external control & 200 \\
\hline 2. & " & Speech shadowing & 63 \\
\hline 3. & $"$ & Simultaneous reading with experimenter & 50 \\
\hline 4. & $"$ & Subject whispers. Experimenter reads aloud & 45 \\
\hline 5. & "I & Delayed auditory feedback (DAF) & 55 \\
\hline 6. & $"$ & Immediate auditory feedback & 55 \\
\hline 9. & $n$ & White noise masking at $110 \mathrm{db}$ & 60 \\
\hline 10. & "I & White noise masking at $117 \mathrm{db}$ & 48 \\
\hline 11. & $"$ & Low pitch (140 cps) masking at $97 \mathrm{db}$ & 51 \\
\hline 8. & $\begin{array}{l}\text { Arthur the } \\
\text { Young Rat }\end{array}$ & Subject reads without external control & 96 \\
\hline 12. & " & Low-pitch (140 cps) masking at $97 \mathrm{db}$ & 49 \\
\hline 13. & $"$ & Low-pitch (140 cps)masking at $97 \mathrm{db}$ switched rapidly on and off & 54 \\
\hline 15. & $"$ & Subject reads without external control & 108 \\
\hline 7. & $\begin{array}{c}\text { From a } \\
\text { periodical }\end{array}$ & Subject reads without external control & 200 \\
\hline 14. & & Subject reads without external control & 155 \\
\hline
\end{tabular}

The author replicated some of the experiments in external control with a male student, aged 20 years. Normally the subject has no difficulty in speaking in the presence of a very young child or a pet animal, and he can sing or cheer in a group. When in the company of his peers or superiors, however, he stutters severely. He has developed a
The results show certain anomalies. Firstly there is a clear indication that external control was associated with improved reading. This can be seen from the first series (i.e. Tests $2,3,4,5,9,10$ and 11) as well as from the second series (Tests 12 and 13). Secondly reading performance also improved when no external control was applied (Tests 
6 and 14). Thirdly it appears as if there is a sequential improvement in reading during the course of the test series, as is clearly demonstrated when the third series is examined. In Tests 7 and 14 no external control was applied, but the performance on Test 14 was a considerable improvement on that of Test 7. However, this sequential improvement does not hold consistently for the first series (Tests $1,2,3,4,5,6,9,10$ and 11 ) or for the second series (Tests 8, 12, 13 and 15), In fact the poorest performance sequentially was on test 15 , when compared with Test 8 . It could be argued that fatigue set in at Test 15 , as a sudden step function, as Test 14 immediately preceding it represented a $22 \%$ reduction in reading time over Test 7 .

To sum up the results of this series of experiments, it may be stated very tentatively that there appears to be a trend for improved reading to be associated with external control. These experiments certainly do not warrant the conclusion that external control per se reduces stuttering. It is apparent that considerable further research, using a larger sample as well as control and experimental conditions alternately, is required - a field in which speech therapists could play an important part.

\section{EXTERNAL CONTROL AND}

\section{STUTTERING}

Results reported by Cherry, Sayers and Marlund (5) and McLaren (11) indicate that considerable success has already been achieved when external control is used in conjunction with other techniques in the treatment of stutterers. McLaren (11) emphasizes that no one technique can be the ideal approach to the problem, as stuttering is an infinitely complex phenomenon, involving speech in the act of communication and is intimately associated with human relationships. Over a period of 3 years external control has been used at St. Mary's Hospital, London, to build up a dynamic technique, adaptable to all ages and types of stutterers. MacLaren (1.1, p. 460) states:

"The young patient - provided that environmental stresses can be relieved responds well to direct auditory retraining.
"With the older patient the anxiety attached to the speech situation often spreads its tentacles through the whole pattern of life. It would be absurd to expect that auditory retraining alone could bring any real relief to such patients. But here our technique has been found to be of great value, for it not only serves to strengthen and reinforce the memory of normality but it can be used as an instrument by which, in a very practical way, the stammerer can be brought to realise in actual experience the nature of his difficulties and the principles which must be followed if he is to free himself from them."

The relationship between stuttering and external control awaits full elucidation. Meanwhile the hypothesis proposed by Cherry, Sayers and Marlund (5) has much to commend it. As they see it, stuttering is mainly mediated by the subject's abnormal perception of the low-frequency components of his own voice, particularly the bone and tissue-conducted larynx tones. They do not suggest that this abnormal perception is a cause of stuttering. The role of external control is then to diminish the stutterer's awareness of the low-frequency laryngeal stimuli by means of masking. If the stutterer's basilar membranes are brought into vibration by means of a loud tone in the region of $140 \mathrm{cps}$, all other hearing stimuli are masked with the result that the perceptual abnormality is effectively blocked and stuttering is diminished.

\section{SUGGESTED FURTHER RESEARCH ON EXTERNAL CONTROL}

On the basis of the work already done in Britain by Cherry, Sayers and Marlund and the somewhat inconclusive results from South African replication of some of their techniques of external control, the author considers that exhaustive research in this field promises well for the development of practical techniques for the alleviation of stuttering.

The author posed the problem of designing a small, portable transistor oscillator capable of producing a stable wave form in the vicinity of 140 cps to the Acoustic Research Laboratory of the Council for Scientific and Industrial Research. Dr. J. F. Burger 
designed and constructed a prototype multivibrator using two transistors to produce a very stable waveform, the frequency of which can be varied very simply by controlling the power supply voltage. The range of frequency is from 123 to $165 \mathrm{cps}$, which is thought to be wide enough to accomodate individual differences in resonant frequency of the basilar membranes of different subjects. Figure 3 shows the circuit diagram of this multi-vibrator, together with the waveform produced and details of changes in frequencies associated with changes in power supply voltage.

FICLRE 3

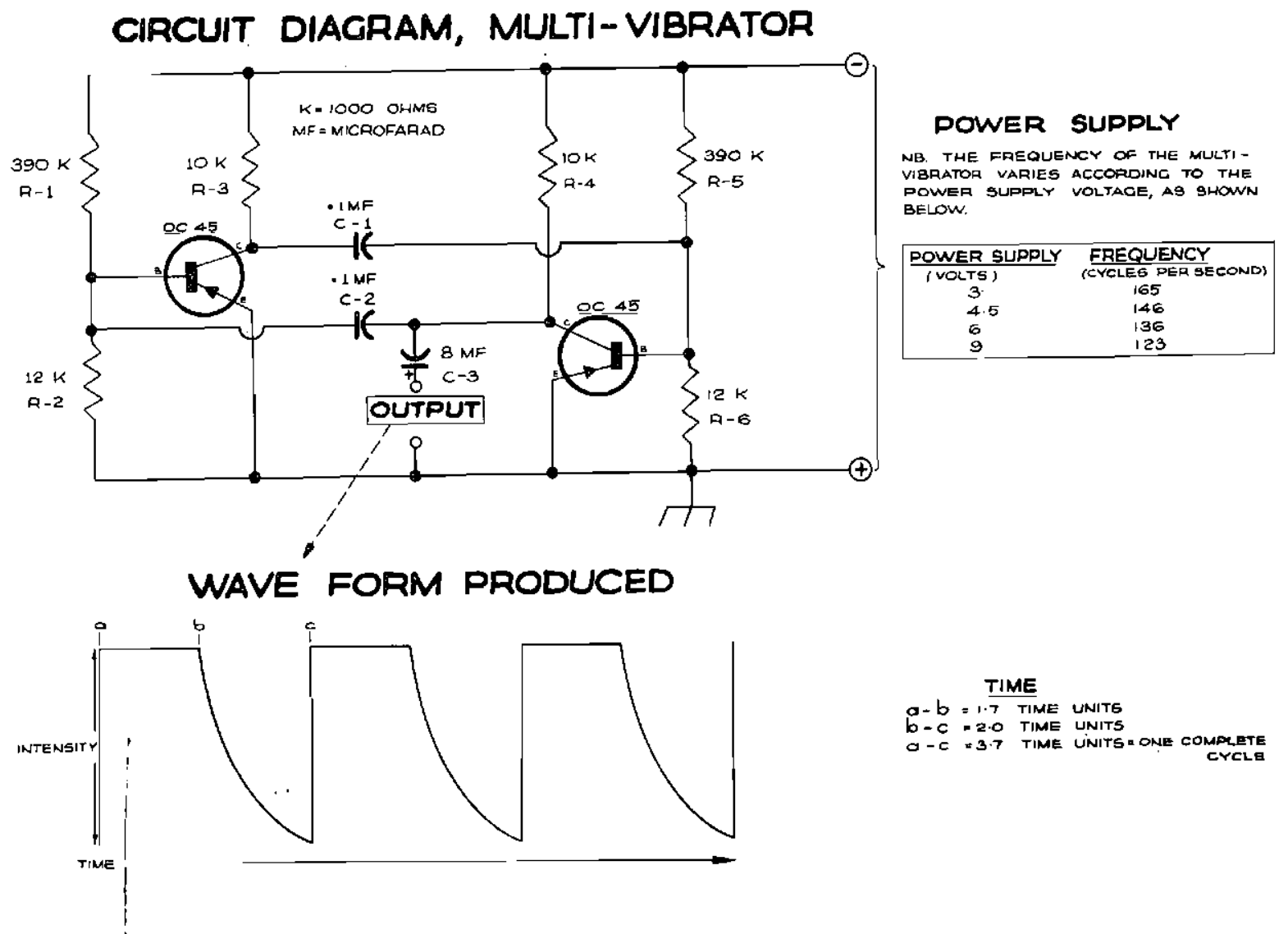


To date, no experiments with stutterers have been performed using this multi-vibrator. However, it is suggested that it could be linked with a transistor power amplifier, microphone, switching system and earphones in a small portable set that could be worn by a stutterer over an extended period.
The proposed system is shown in Figure 4. The circuit has been so designed that output from either the multi-vibrator or the microphone can be fed to the earphones after amplification. Thus, when the stutterer is listening, he switches the microphone into and the multi-vibrator out of circuit.

FIOURE 4

\section{BLOCK DIAGRAM, MULTI-VIBRATOR MICROPHONE, AMPLIFIER SWITCHING}

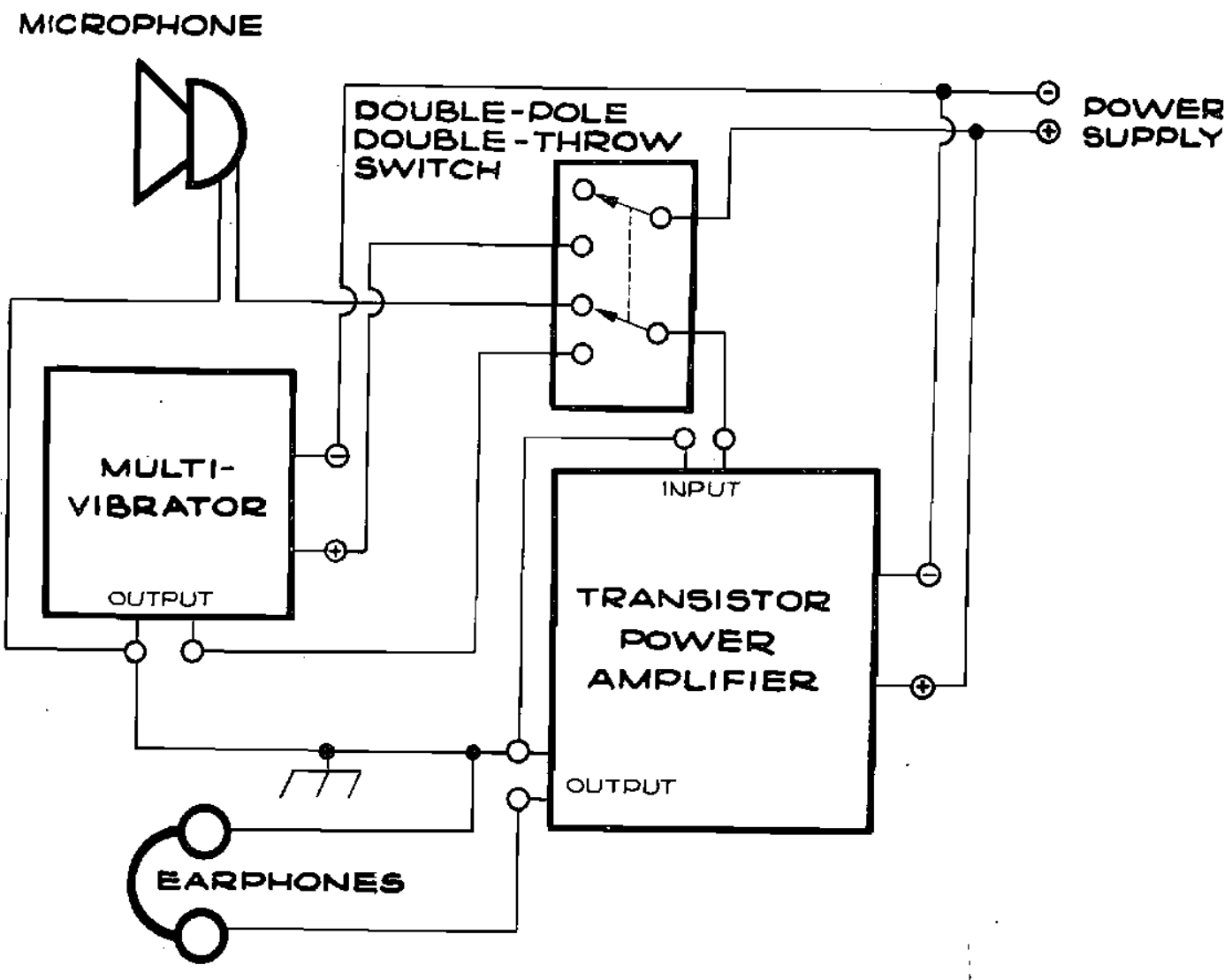


When he wishes to speak, he switches the microphone out of and the multi-vibrator in. to the circuit. This then produces the characteristic squeal in the earphones setting his basilar membranes into vibration and obliterating all perception of voice tones. For cosmetic reasons the earphones could be of the hearing-aid type.

Should this proposed system evoke the desired effect of inhibiting stuttering through the masking of the stutterer's perception of low-frequency components of his voice, it is further suggested that therapy could proceed along the lines ..f the Hullian learning theory of reinforcement, immediate reward, massing of reinforcer ${ }_{i}$ ent, reactive inhibition and controlled inhibition as proposed by Walton and Black (15). In effect then the external control would constitute a temporary "crutch" to the stutterer during the process of auditory reconditioning.

While this paper was in preparation, the author's attention was drawn to the work of Parker ard Christopherson (8), of Whittingham Hospital, Nr. Preston, Lancashire. Using a small transistor tone producing apparatus which the patient could switcil off or on at will, when desiring to hear or speak, they successfully treated three stutterers, two of whom had received no benefit frum conventional speech therapy.

Finally, the author's attention has been drawn to the as yet unpublished work of Dr. C. D. Roode (Dept., of Psychology, University of Potchefstroom) on ear dominance and cerebral speech localization, at the University of Ottawa. In the light of this work it would appear that research into ear dominance may well be a major factor in elucidating the aetiology and treatnent of speech defects.

\section{SUMMARY}

Some results from South African experiments with delayed auditory feedback are presented, from which it is apparent that reading performance of male former stutterers differs from that of males with no reported history of stuttering. The CherrySayers-Marlund experiments in the field of external controls and stuttering are reviewed and some results from South African replication of some of these experiments with a male stutterer are presented. A transistor multi-vibrator with interesting research and clinical possibilities is described. Recent work in Britain and Canada is mentioned and some suggestions for future research are made.

\section{OPSOMMING}

Resultate van Suid-Afrikaanse proewe op die gebied van vertraagde akoestiese terugvoering word aangebied, waaruit blyk dat daar verskille in leesprestasie bestaan tussen manlike gewese hakkelaars en mans met geen aangemelde hakkel-geskiedenis. Die Cherry-Sayers-Marlund proewe ten opsigte van eksterne kontroles en hakkel word gemeld tesaam met navorsingsgegewens uit die herhaling van sommige van hierdie proewe met 'n manlike hakkelaar in Suid-Afrika. 'n Transistor multi-vibrator met interessante navorsings-en kliniese moontlikhede word beskrywe. Onlangse werk in Brittanje en Kanada word genoem en voorstelle vir toekomstige navorsing word voorgelê.

\section{ACKNOWLEDGEMENTS}

Many persons and institutions made the present paper possible. Whilst expressing his thanks to them, the author emphasizes that the views stated are his own and do not represent those of any person or institution mentioned below:

The National Council for Social Research of the Department of Education, Arts and Science gave financial assistance. Dr. S. Biesheuvel, former Director of the National Institute for Personnel Research and his successor. Dr. D. J. Gouws made apparatus and facilities available. The study was conducted for degree purpose at the University of Pretoria under the joint guidance of Prof. D. J. Swiegers and Dr. H. Reuning. Many members of the NIPR assisted at various stages: mostly as patient and forebearing subjects. Mr. D. R. de Wet assisted in the design of the equipment, Miss S. Kaan and Messrs. A. O. H. Roberts and J. Shepherd advised on and assisted with statistical processing. The DAF apparatus was modified by Mr. T. Dicker to the design of Mr. J. Kidd, both of the CSIR Central Workshops. Mr. W. Keet of the CSIR Acoustic Research Laboratory assisted with initial DAF experiments and Dr. J. F. Burger of the same laboratory designed and constructed the proto-type multi-vibrator. Mr. R. Serdyn of the CSIR took the photographs and Miss E. Woudstra of the NIPR prepared the diagrams. Professors E. Pratt-Yule, E. Wild, C. Danziger and R. Albino and their colleagues and students made facilities available and co-operated in the experiments at the Universities of Cape Town, Rhodes (Grahamstown) and Natal (Pietermaritzburg and Durban). 


\section{BIBLIOGRAPHY}

1. Black, J. W. The Effect of delayed side -tone upon vocal-rate and intensity. J. Speech and Hearing Disorders, 16, 56-60. 1951.

2. Black, J. W. The persistence of the effects of delayed side-tone. J. Speech and Hearing Disorders, 20, 65-68., 1955.

3. Böhr, J. W. F. A technical note on the design and construction of an apparatus for producing delayed auditory feedback. Paper presented to the XIIIth Annual Congress, South African Psychological Association, Stellenbosch, 1961, 8p.

4. Böhr, J. W. F. Vertraagde akoestiese terugvoering by persone met en sonder spraakgebreke. Referaat gelewer voor departementele sielkundiges, Skoolkliniek, Transvaalse Onderwysdepartement, Pretoria, April 1963. 15p.

5. Cherry, C., Sayers, B. McA. \& Marlund, Pauline. Experiments upon the total inhibition of stammering by external control and some clinical results. J. Psychosom. Res., 1956, 1, 223-246; reprinted in Eysenck, H. J. (editor). Behaviour Theory and the Neuroses. Oxford: Pergamon Press, 1960, 441-456.

6. Fairbanks, G. \& Jaeger, R. A device for continuously variable time delay of headset monitoring during magnetic recording of speech. J. Speech and Hearing Disorders, 16, 162-164. 1951.

7. Hanley, C. N. \& Tiffany, W. R. An investigation into the use of electro-mechanically delayed side-tone in auditory testing. J. Speech and Hearing Disorders, 19, 367-374. 1954.

8. Johnson, W., Brown, C. F., Curtis, J.F., Edney, C. W. \& Keaster, J. Speech Handicapped Children, New York:Harper, p. 422, 1948.

9. Ladefoged, P. The perception of speech. Proc. Symposium on Mechanization and Thought Processes, 320-333, 1958.

10. Lee, B. S. Some effects of side-tone delay. J. Acoust. Soc. Amer., 22, 639-640. 1950.

11. MacLaren, J. The treatment of stammering by the Cherry-Sayers method. In Eysenck (see 5. above), 441-456.

12. Marple, N. B. \& Morrill, S. N. A device for the production of delayed side-tone. Joint Project, NM 001 064. 01.08, Report no. 8 Pensacola, Ohio State University.

13. Parker, C. S. \& Christopherson, F. Electronic aid in the treatment of stammer. Med. Electron. Biol. Engng., Vol. 1. No.1. 121-125. 1963.

14. Tiffany, W. R., Hanley, C. N. \& Sutherland, L. C. A simple mechanical adapter for variable side-tone delay. J. Speech and Hearing Disorders, 115, 59-60. 1954.

15. Van Riper, C. Speech Correction Principles and Methods. New York: Prentice -Hall, 163-164, 1939.

16. Walton, D. \& Black, D. A. The application of learning theory to the treatment of stammering. J. Psychosom. Res. 3 , 170-179; 1958 also reprinted in Eysenck, H. (see 5 above), 123-134. 